\title{
AMMONIA LOSSES ESTIMATED BY AN OPEN COLLECTOR FROM UREA APPLIED TO SUGARCANE STRAW(1)
}

\author{
Eduardo Mariano(2), Paulo Cesar Ocheuze Trivelin $^{(3)}$, Michele Xavier \\ Vieira $^{(2)}$, José Marcos Leite ${ }^{(2)}$, Rafael Otto ${ }^{(2)} \&$ Henrique Coutinho \\ Junqueira Franco(4)
}

\begin{abstract}
SUMMARY
The quantification of ammonia $\left(\mathrm{NH}_{3}\right)$ losses from sugarcane straw fertilized with urea can be performed with collectors that recover the $\mathrm{NH}_{3}$ in acid-treated absorbers. Thus, the use of an open $\mathrm{NH}_{3}$ collector with a polytetrafluoroethylene (PTFE)-wrapped absorber is an interesting option since its cost is low, handling easy and microclimatic conditions irrelevant. The aim of this study was to evaluate the efficiency of an open collector for quantifying $\mathrm{NH}_{3}-\mathrm{N}$ volatilized from urea applied over the sugarcane straw. The experiment was carried out in a sugarcane field located near Piracicaba, São Paulo, Brazil. The $\mathrm{NH}_{3}-\mathrm{N}$ losses were estimated using a semi-open static collector calibrated with ${ }^{15} \mathrm{~N}$ (reference method) and an open collector with an absorber wrapped in PTFE film. Urea was applied to the soil surface in treatments corresponding to rates of 50, 100, 150 and $200 \mathrm{~kg} \mathrm{ha}^{-1} \mathrm{~N}$. Applying urea-N fertilizer on sugarcane straw resulted in losses $\mathrm{NH}_{3}-\mathrm{N}$ up to $24 \%$ of the applied rate. The amount of volatile $\mathrm{NH}_{3}-\mathrm{N}$ measured in the open and the semi-open static collector did not differ. The effectiveness of the collection system varied non-linearly, with an average value of $58.4 \%$ for the range of 100 to $200 \mathrm{~kg} \mathrm{ha}^{-1}$ of urea-N. The open collector showed significant potential for use; however, further research is needed to verify the suitability of the proposed method.

Index terms: Saccharum spp., nitrogen, $\mathrm{N}$ fertilization, volatilization, collection system.
\end{abstract}

(1) Part of MSc. Thesis of the first author. Received for publication in June 9, 2011 and approved in December $22,2011$.

(2) Luiz de Queiroz College of Agriculture, University of São Paulo - USP. Caixa Postal 9, Av. Pádua Dias 11, CEP 13418-900 Piracicaba (SP), Brazil. E-mails: emariano@cena.usp.br; mxvieira@cena.usp.br; jmleite@cena.usp.br; rotto@esalq.usp.br

(3) Center for Nuclear Energy in Agriculture, University of São Paulo - USP. Av. Centenário 303, Caixa Postal 96, CEP 13416-000 Piracicaba (SP), Brazil. E-mail: pcotrive@cena.usp.br

(4) Brazilian Bioethanol Science and Technology Laboratory, Brazilian Research Center in Energy and Materials - CNPEM. Rua Giuseppe Máximo Scolfaro 10.000, Caixa Postal 6192, CEP 13083-970 Campinas (SP), Brazil. E-mail: henrique.franco@bioetanol.org.br 


\title{
RESUMO: PERDASDE AMÔNIA ESTIMADAS POR UMCOLETOR ABERTO A PARTIR DE UREIA APLICADA SOBRE PALHADA DE CANA- $D E-A C ̧ U ́ C A R$
}

\begin{abstract}
A quantificação das perdas de amônia $\left(\mathrm{NH}_{3}\right)$ proveniente da aplicação de ureia sobre a palhada de cana-de-açúcar pode ser realizada com uso de coletores, que recuperam o $\mathrm{NH}_{3}$ em absorvedores acidificados. Desse modo, o uso de coletor aberto com absorvedor envolto em pelicula de politetrafluoroetileno (PTFE) torna-se uma opção interessante, pois apresenta baixo custo, fácil manuseio, além de não interferir nas condições microclimáticas. $O$ objetivo deste estudo foi avaliar a eficiência de um coletor aberto na quantificação do $\mathrm{N}-\mathrm{NH}_{3}$ volatilizado da ureia aplicada sobre solo coberto com restos vegetais de cana-deaçúcar. O experimento foi desenvolvido em área de cana-de-açúcar localizada na região de Piracicaba, Estado de São Paulo, Brasil. As perdas de $\mathrm{N}-\mathrm{NH}_{3}$ foram estimadas pelo coletor semi-aberto estático calibrado com ${ }^{15} \mathrm{~N}$ (método de referência) e coletor aberto com absorvedor envolto em pelicula de PTFE. A ureia foi aplicada sobre a superfície do solo, em tratamentos que corresponderam às doses de 50, 100, 150 e $200 \mathrm{~kg} \mathrm{ha}^{-1}$ de N. A aplicação de ureia fertilizante sobre a palhada da cana-de-açúcar resultou em perdas de $\mathrm{N}$ - $\mathrm{NH}_{3}$ de até $24 \%$ da dose aplicada. O coletor aberto não alterou a quantidade de $\mathrm{N}-\mathrm{NH}_{3}$ volatilizada em relação a coletor semi-aberto estático. A eficiência do sistema coletor variou de forma não linear, com valor médio de 58,4\% na faixa de 100 a $200 \mathrm{~kg} \mathrm{ha}^{-1}$ de $\mathrm{N}$-ureia. O coletor aberto apresentou expressivo potencial de uso, porém novas pesquisas são necessárias visando à adequação do método proposto.
\end{abstract}

Termos de indexação: Saccharum spp., nitrogênio, adubação nitrogenada, volatilização, sistema coletor.

\section{INTRODUCTION}

The emission of nitrogen as ammonia $\left(\mathrm{NH}_{3}\right)$ into the atmosphere is estimated at about $54 \mathrm{Tg}_{\text {year }}{ }^{-1}$, of which $75 \%$ is caused by human activity (Laegreid et al., 1999). Mineral fertilizers and organic residues applied to the soil represent close to $23 \%$ of global $\mathrm{NH}_{3}-\mathrm{N}$ emissions (Bouwman et al., 2002). These $\mathrm{N}$ losses do not only reduce the economic efficiency of nitrogen fertilizers, but also harm the environment. Ammonia gas emitted into the atmosphere is generally deposited near the source of emission, promoting the acidification and eutrophication of natural ecosystems (Sommer et al., 2004).

The $\mathrm{NH}_{3}-\mathrm{N}$ losses by volatilization from urea, the most widely used source of mineral nitrogen worldwide (Sommer et al., 2004), generally vary from 20 to $40 \%$ of applied $\mathrm{N}$ in the case of soil surfaces covered with crop residues of sugarcane (Saccharum spp.) (Prammanne et al., 1989; Freney et al., 1994; Cantarella et al., 2008). Sugarcane straw favors $\mathrm{NH}_{3}$ losses by volatilization because the activity of the enzyme urease is higher in plants and plant residues than in soil. Rochette et al. (2009) found that ureolytic activity and the resulting $\mathrm{NH}_{3}-\mathrm{N}$ volatilization after the surface application of urea was higher in soil with crop residue on the surface in comparison to conventionally tilled soil. The incorporation of urea into the soil under sugarcane straw can reduce the volatilization, but the operational efficiency of this method is low and its cost high.

The methods for quantifying $\mathrm{NH}_{3}-\mathrm{N}$ volatilized from soil can be classified as direct and indirect. Indirect estimates can be obtained by isotope balancing with ${ }^{15} \mathrm{~N}$ (Lara Cabezas \& Trivelin, 1990). However, the high cost of ${ }^{15} \mathrm{~N}$ hinders its use under field conditions. ${ }^{15} \mathrm{~N}$ is also used to calibrate direct methods, which are based on capturing $\mathrm{NH}_{3}$ volatilized in acid medium (Lara Cabezas et al., 1999; Araújo et al., 2009). These methods can be classified as closed static collector (Sommer \& Olesen, 1991), closed dynamic collector (Kissel et al., 1977) and semi-open static collector (Nömmik, 1973). Currently, micrometeorological methods are also used; these are considered to be more accurate as they do not change the environmental conditions close to the soil surface (Sommer et al., 2004). However, these methods require extensive experimental areas (larger than a hectare) that usually need to be flat, as well as sophisticated equipment (such as micro anemometers and gas detectors), making them costly and unviable for field studies with multiple treatments.

The semi-open static collector (SOC), though often used in field studies, has limitations in quantifying volatilization under natural conditions due to changes in the atmospheric environment above the soil surface (such as temperature, relative humidity, rate of water evaporation and $\mathrm{NH}_{3}$ vapor 
pressure) caused by the presence of the collection chamber (Lara Cabezas \& Trivelin, 1990; Lara Cabezas et al., 1999). An alternative to this method is the use of collection systems that favor airflow in the area that captures volatilized $\mathrm{NH}_{3}$. Therefore, an open collector $(\mathrm{OC})$ with an absorber wrapped in polytetrafluoroethylene (PTFE) film has been proposed; this option seems interesting because of its low cost, easy handling and great potential for use under field conditions (Campana, 2008; Alves et al., 2011). OC consists of a rigid polyvinyl chloride (PVC) plate and foam saturated in an acid solution that absorbs $\mathrm{NH}_{3}$, and both are wrapped in PTFE film. The PTFE film is permeable to $\mathrm{NH}_{3}$ gas (Sørensen \& Jensen, 1991). In this context, the use of a SOC calibrated using ${ }^{15} \mathrm{~N}$ as performed by Lara Cabezas et al. (1999) enables the evaluation of alternative systems to capture $\mathrm{NH}_{3}$ volatilized from soil under field conditions.

Therefore, the purpose of this study was to evaluate the effectiveness of $\mathrm{NH}_{3}$ capture by an open collector with an absorber wrapped in PTFE film using a semi-open static collector to quantify $\mathrm{NH}_{3}-\mathrm{N}$ volatilized from urea applied to sugarcane residue in an area of commercial production.

\section{MATERIALS AND METHODS}

The experiment was performed from September 28 to October 28, 2009, on a commercial sugarcane plantation of the Iracema Mill $\left(22^{\circ} 35^{\prime} \mathrm{S} ; 47^{\circ} 37^{\prime} \mathrm{W}\right.$; $619 \mathrm{~m}$ asl) near Piracicaba, São Paulo, Brazil. The local climate is tropical and, according to the Köppen climate classification, mesothermal, with a dry winter (Cwa) transitioning to a humid winter (Cfa). The mean annual rainfall is $1,275 \mathrm{~mm}$, and the average temperature between $24.6^{\circ} \mathrm{C}$ (in February) and $17.4^{\circ} \mathrm{C}$ (in July). The soil is classified as Typic Hapludox (Soil Survey Staff, 2010). The following characteristics were determined in the $0-20 \mathrm{~cm}$ soil layer: $\mathrm{pH} 4.6$ in $0.01 \mathrm{~mol} \mathrm{~L}^{-1} \mathrm{CaCl}_{2}$ (1: 2.5 soil: solution - $\mathrm{m} / \mathrm{v}) ; 95.3 \mathrm{mmol}_{\mathrm{c}} \mathrm{dm}^{-3}$ cation exchange capacity (CEC) (Raij et al., 2001); $23.8 \mathrm{~g} \mathrm{~kg}^{-1}$ total organic $\mathrm{C}$ and $1.4 \mathrm{~g} \mathrm{~kg}^{-1}$ total $\mathrm{N}$, both determined by a mass spectrometer with an automated $\mathrm{C}$ and N analyzer (ANCA-GSL model, 20-20, Sercon, Crewe, UK) (Barrrie \& Prosser, 1996); and $630 \mathrm{~g} \mathrm{~kg}^{-1}$ clay, determined by the densimeter method (Gee \& Bauder, 1986).

Sugarcane (cultivar SP89-1115) was planted on March 8, 2008, in rows spaced $1.5 \mathrm{~m}$ apart. The cane was mechanically harvested without burning cane straw, on June 15, 2009, and the crop residues (tips, leaves and pieces of stalk) were left on the soil surface. The dry weight of straw left on the field $\left(17.2 \pm 3.1 \mathrm{Mg} \mathrm{ha}^{-1}\right)$ was determined by sampling $1 \mathrm{~m}^{2}$ areas (20 replications). The experiment was set up during the first ratoon cycle and began 105 days after harvesting.

The experiment had a randomized block design and the treatments consisted of four $\mathrm{N}$ rates (50; 100; 150 and $200 \mathrm{~kg} \mathrm{ha}^{-1} \mathrm{~N}$ ) with four replications. Urea was manually applied over the sugarcane straw (granules containing $46 \% \mathrm{~N}$ ) in a line $20 \mathrm{~cm}$ away from the sugarcane row on only one side of each row. Both collector types, SOCs and OCs, were installed in each experimental plot (one unit of each collector per replication) to measure volatilized $\mathrm{NH}_{3}-\mathrm{N}$. In each block, one control was included to evaluate $\mathrm{NH}_{3}$ losses from the mineralization of straw-covered soil. The $\mathrm{NH}_{3}$ losses from these plots were subtracted from those treated with urea.

The SOC (Figure 1a) was proposed by Nömmik (1973) and adapted by Lara Cabezas \& Trivelin (1990). Cylindrical chambers were fixed on top of PVC bases that were partially inserted into the soil, maintaining the sugarcane straw within. Each SOC has three PVC bases, and the collectors were moved between these bases every time the foam disc was replaced and/or when rain fell during the sampling interval, according to the method described by Cantarella et al. (2003) and Costa et al. (2003). This procedure reduces the microclimate effect within the collector and exposes the fertilizer within the bases to rain and wind (Cantarella et al., 2008). Therefore, the urea was exposed to the same climatic conditions as in the remaining experimental plots.

The OC, modified according to Alves et al. (2011), consisted of a $16 \times 16 \times 0.2 \mathrm{~cm}$ rigid PVC plate (Figure 1b). An $\mathrm{NH}_{3}$ absorber consisting of polyethylene foam, identical to that used in

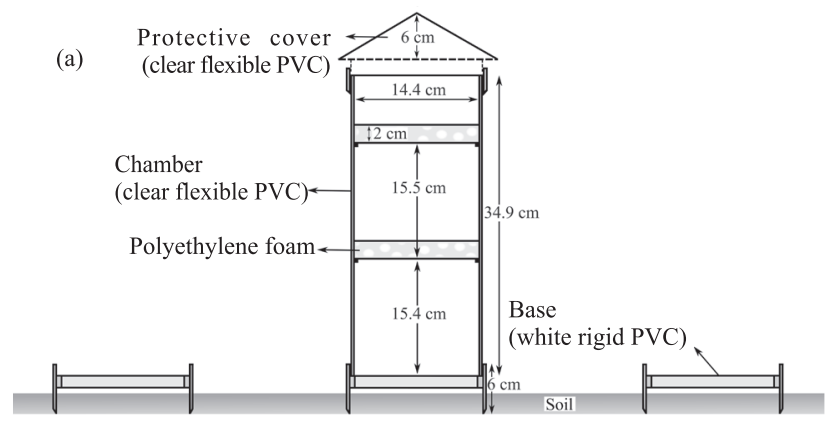

(b)

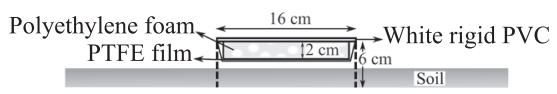

Figure 1. A semi-open static collector and its respective PVC bases (a) and an open collector with an absorber wrapped in PTFE film (b) used to quantify $\mathrm{NH}_{3}-\mathrm{N}$ volatilized from urea applied over sugarcane straw. Adapted from Lara Cabezas \& Trivelin (1990) and Alves et al. (2011). 
the SOC (diameter $14.4 \mathrm{~cm}$, thickness $2 \mathrm{~cm}$ and density $0.02 \mathrm{~g} \mathrm{~cm}^{-3}$ ), was fixed to the underside of the plate. The absorbing foam and PVC plate were wrapped in PTFE film. The PTFE kept the PVC plate and absorbing foam in place, and is highly $\mathrm{NH}_{3}$ permeable as well (Sørensen \& Jensen, 1991). The function of the PVC plate on top of the OC is to prevent $\mathrm{NH}_{3}$ absorption from soil and atmosphere. The collectors were supported by four metal rods horizontally at $1 \mathrm{~cm}$ from the soil surface. Unlike the SOC, which rotated periodically between the bases, the OCs remained in the same place throughout the experiment.

The urea contained within the SOC bases and under the OC bases, taking each treatment into account, was weighed and applied to the surface over the sugarcane straw. The foam absorbers used for both collector systems were previously soaked in approximately $30 \mathrm{~mL}$ of orthophosphoric acid $\left(1.5 \mathrm{~mol} \mathrm{~L}^{-1}\right.$ solution with $5 \%$ glycerol $\left.-\mathrm{v} / \mathrm{v}\right)$, packed in plastic bags and stored in a freezer $\left(-15^{\circ} \mathrm{C}\right)$ until they were used in the experiment to avoid contamination with $\mathrm{NH}_{3}$ from air.

The foam absorbers were collected and replaced 2 , $4,6,8,11,14,18,22,26$ and 30 days after treatment application. To determine the $\mathrm{NH}_{3}$ retained in the absorbers, $\mathrm{NH}_{3}$ was extracted by washing the foam with $450 \mathrm{~mL}$ of deionized water. The $\mathrm{NH}_{4}{ }^{+}-\mathrm{N}$ from the samples was determined by a flow injection analysis system (FIA) through the formation of $\mathrm{NH}_{3}$ in alkaline medium in a permeable hydrophobic membrane (consisting of PTFE) from where the flow was directed to a conductivity cell (Reis et al., 1997). The results of volatilized $\mathrm{N}$ from the SOCs (NVdSOC, $\mathrm{kg} \mathrm{ha}^{-1}$ ) were corrected using the calibration equations proposed by Lara Cabezas et al. (1999), whereas the OC ( $\left.\mathrm{NVaOC}, \mathrm{kg} \mathrm{ha}^{-1}\right)$ results represented the $\mathrm{NH}_{3}-\mathrm{N}$ absorbed and extrapolated to one hectare, considering the $6,667 \mathrm{~m} \mathrm{ha}^{-1}$ application range (0.1 $\mathrm{m}$ strip width).

The efficiency (E) of an $\mathrm{OC}$ to quantify $\mathrm{NH}_{3}-\mathrm{N}$ volatilization from soil in relation to $\mathrm{N}$ volatilization from a SOC was defined by the following equation (Equation 1):

$$
E(\%)=\frac{(N V a C A)}{(N V d C S A)} \cdot 100
$$

where $E(\%)=$ efficiency of an $\mathrm{OC}$ in the quantification of $\mathrm{NH}_{3}-\mathrm{N}$ volatilization; $N V a C A=$ amount of volatilized $\mathrm{NH}_{3}-\mathrm{N}$ absorbed by the OC (kg ha-1); $N V d S O C=$ amount of volatilized $\mathrm{NH}_{3}-\mathrm{N}$ determined by the SOC $\left(\mathrm{kg} \mathrm{ha}^{-1}\right)$.

The soil moisture content was measured simultaneously with the collection and replacement of the foam absorbers by collecting four undisturbed topsoil (depth $0-20 \mathrm{~cm}$ ) samples from the control plot. The water content was determined after oven-drying the samples at $105{ }^{\circ} \mathrm{C}$ for $48 \mathrm{~h}$. The air temperature was monitored $2 \mathrm{~m}$ above the soil surface by an automated weather station installed close to the experimental area, and the data were stored in a data logger (CR200 model, Campbell Scientific $^{\circledR}$, Logan, USA).

The $\mathrm{NH}_{3}-\mathrm{N}$ losses estimated using the collection systems were subjected to variance analysis and the means compared by Tukey's test at 0.05 . The best model was adjusted to correlate the volatilized $\mathrm{NH}_{3}-\mathrm{N}$ absorbed by the collection systems.

\section{RESULTS AND DISCUSSION}

During the experimental period, the average air temperature varied between 16.2 and $26.8^{\circ} \mathrm{C}$, whereas the soil moisture content in the $0-20 \mathrm{~cm}$ layer had a small range from 143 to $193 \mathrm{~g} \mathrm{~kg}^{-1} \mathrm{H}_{2} \mathrm{O}$ (Figure 2). Rainy weather, which was atypical for the time of year, prevailed in the region of Piracicaba, and heavy rain occurred at the experimental site, especially after the first 15 days. Rainfall, with a total of $142 \mathrm{~mm}$ in the 30 days of the evaluation, is very important for $\mathrm{NH}_{3}-\mathrm{N}$ volatilization because it dissolves and hydrolyzes the soil-applied urea (Prasertsak et al., 2002) and maintains a higher moisture content in the residues and soil surface, thus increasing the $\mathrm{NH}_{3}-\mathrm{N}$ losses (Freney et al., 1992). Other environmental factors that directly influence volatilization are soil temperature and pH (Sommer \& Olesen, 1991), relative humidity (Cabrera et al., 2010), wind speed (Sommer et al., 1991), and the concentration of $\mathrm{N}$ fertilizer in the soil (Cabrera et al., 1991).

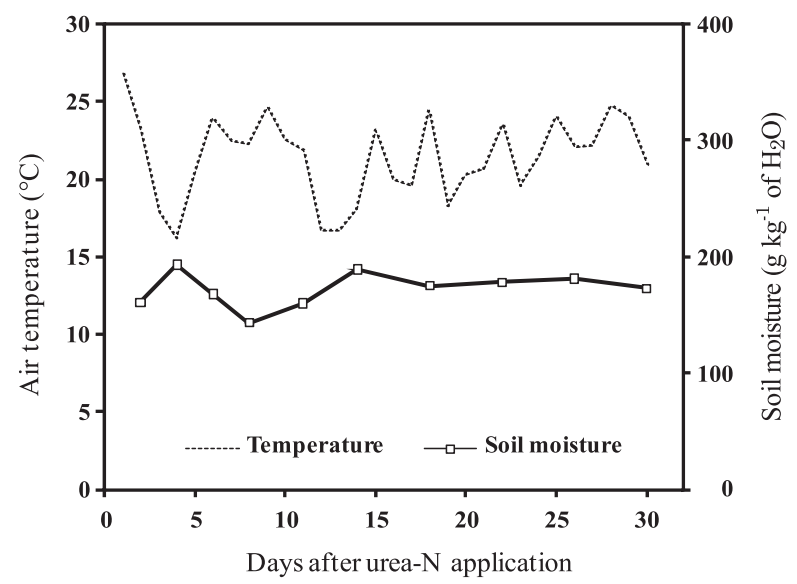

Figure 2. Mean air temperature and soil moisture content in the surface layer $(0-20 \mathrm{~cm})$ during the experiment performed in Piracicaba, São Paulo, Brazil. 
The rainfall pattern appeared to be the determining component of $\mathrm{NH}_{3}$ volatilization. A few hours after urea application and installation of the collection systems, there was a $23 \mathrm{~mm}$ rainfall (Figure 3), which was insufficient to incorporate the fertilizer into the soil. Due to the presence of plant residue on the surface, more water was required to reduce the urea-N losses by volatilization (Haysom et al., 1990), because the water naturally flows in the channels formed in the crop residues, thus reducing the capacity for dissolution and incorporation of urea into the soil (Freney et al., 1994; Cabrera et al., 2005; Rochette et al., 2009). Calcino \& Burgess (1995) found that a rainfall of $23 \mathrm{~mm}$ was not enough to dissolve all urea and incorporate it into soil covered with sugarcane residue.

Therefore, the rainfall that occurred on the first day after $\mathrm{N}$ fertilization resulted in the dissolution and hydrolysis of urea by urease, an enzyme produced by microorganisms and found intracellularly and extracellularly in soil (Klose \& Tabatabai, 2000). Urease is more active in soil covered with crop residues than in tilled soil (Rochette et al., 2009). The hydrolysis of the fertilizer generates $\mathrm{NH}_{4}{ }^{+}-\mathrm{N}$ and $\mathrm{NH}_{3}-\mathrm{N}$ ions, which increases the $\mathrm{pH}$ around the fertilizer granules (Sherlock et al., 1987) and consequently increases the losses of urea- $\mathrm{N}$ applied on sugarcane straw (Freney et al., 1992; Prasertsak et al., 2002). The $15 \mathrm{~mm}$ rainfall on the $15^{\text {th }}$ day after fertilization caused a small increase in $\mathrm{NH}_{3}$ volatilization, although the potential for losses is reduced during

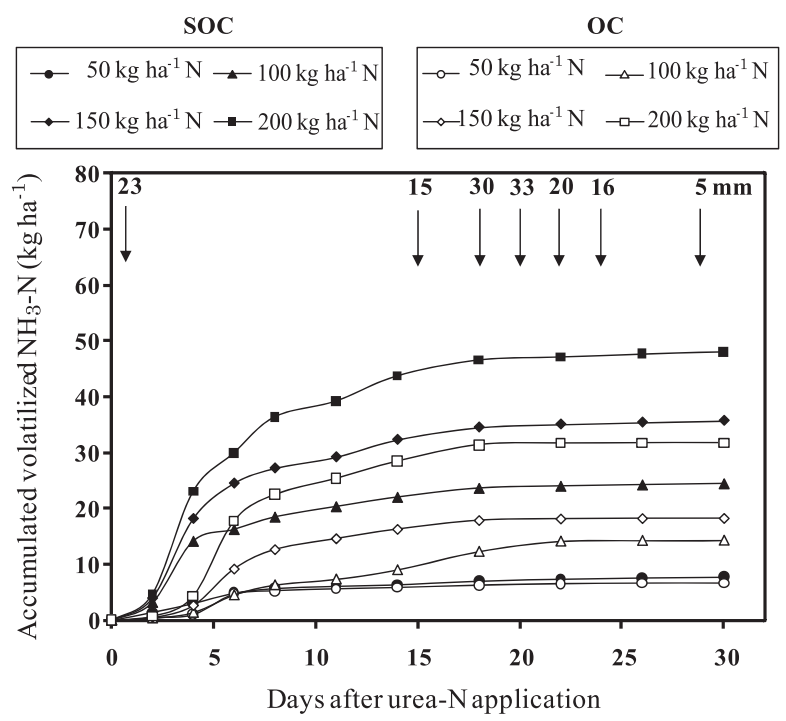

Figure 3. Cumulative volatilized $\mathrm{NH}_{3}-\mathrm{N}$ in 30 days after fertilization, as estimated by two collection methods: a semi-open static collector (SOC) and an open collector with an absorber wrapped in PTFE film (OC). The arrows indicate rainfall events, and the numbers above them indicate the rainfall quantity $(\mathrm{mm})$. this stage (Lara Cabezas \& Trivelin, 1990). The $\mathrm{NH}_{3}-\mathrm{N}$ losses stabilized after a $30 \mathrm{~mm}$ rainfall event, 18 days after the application of $\mathrm{N}$ fertilizer, evidently by incorporating the remaining urea and its hydrolysis products into the soil (Prasertsak et al., 2002), which considerably decreased $\mathrm{NH}_{3}-\mathrm{N}$ emissions after day 19 of the treatment.

The $\mathrm{NH}_{3}-\mathrm{N}$ losses by volatilization were highest in the first week after $\mathrm{N}$ fertilization (Table 1), as has been reported by other authors (Lara Cabezas \& Trivelin, 1990; Costa et al., 2003). The daily $\mathrm{NH}_{3}-\mathrm{N}$ loss rates during the first six days were 3.6, 2.7 and 1.7 times higher by the SOC than by the OC method, respectively, for $\mathrm{N}$ rates of 100,150 and $200 \mathrm{~kg} \mathrm{ha}^{-1}$. These results could be associated with the maintenance of the OC apparatus in the same position during the measurements, while the SOC chambers were alternated between the PVC bases during the experiment. Changing the SOC chambers position over the time allowed the contact of $\mathrm{N}$ fertilizer granules with rainfall and wind, decreasing the microclimatic effect within the chamber. By the OC method, the contact between $\mathrm{N}$ fertilizer granules and rainfall was probably delayed, decreasing urea hydrolysis, when compared with the SOC method, resulting in lower $\mathrm{NH}_{3}-\mathrm{N}$ losses in the first 6 days after fertilization. Campana (2008) also observed a lower $\mathrm{NH}_{3}-\mathrm{N}$ absorption by the OC than by the SOC method in the first 6 days after the application of $100 \mathrm{~kg} \mathrm{ha}^{-1} \mathrm{~N}$ as urea to a pasture soil. Campana (2008) explained the lower $\mathrm{NH}_{3}-\mathrm{N}$ recovery by the OC method as being a result of the saturation of the foam surface due to the intense reaction between the acid and $\mathrm{NH}_{3}-\mathrm{N}$ volatilized during the first 6 days.

Table 1. Daily rates of $\mathrm{NH}_{3}-\mathrm{N}$ volatilization from urea applied onto sugarcane straw as estimated by two collection systems in different subperiods during the experiment

\begin{tabular}{|c|c|c|c|c|}
\hline \multirow{2}{*}{$\begin{array}{c}\text { Collection } \\
\text { system }\end{array}$} & \multicolumn{4}{|c|}{ Daily rate of $\mathrm{NH}_{3}-\mathrm{N}$ loss $\left(\mathrm{kg} \mathrm{ha}^{-1} \mathrm{day}^{-1}\right)$} \\
\hline & 50 & 100 & 150 & 200 \\
\hline & \multicolumn{4}{|c|}{$\begin{array}{c}\mathrm{kg} \mathrm{ha}^{-1} \text { of urea-N } \\
0 \text { to } 6 \text { days }\end{array}$} \\
\hline $\operatorname{SOC}^{(1)}$ & 0.81 & $2.70 \mathrm{a}^{*}$ & $4.09 \mathrm{a}$ & $5.00 \mathrm{a}$ \\
\hline $\mathrm{OC}^{(2)}$ & \multicolumn{3}{|c|}{7 to 14 days } & $2.96 \mathrm{~b}$ \\
\hline $\mathrm{SOC}$ & 0.19 & 0.72 & 0,98 & 1.73 \\
\hline \multirow[t]{2}{*}{$\mathrm{OC}$} & 0.15 & 0.56 & 0.89 & 1.34 \\
\hline & \multicolumn{4}{|c|}{15 to 30 days } \\
\hline SOC & 0.09 & 0.33 & 0.21 & 0.27 \\
\hline $\mathrm{OC}$ & 0.05 & 0.15 & 0.12 & 0.21 \\
\hline
\end{tabular}

(1) SOC: semi-open static collector. ${ }^{(2)}$ OC: open collector with an absorber wrapped in PTFE film. * Means followed by different letters in each column, for each subperiod, differ significantly by Tukey's test $(\mathrm{p}<0.05)$. 
From day 7 onwards, the $\mathrm{NH}_{3}-\mathrm{N}$ volatilization rate for all treatments sank to below that of the previous subperiod. The hypotheses for the decline in loss rates beginning between 5 and 10 days after urea application were based on a reduction in the concentration of ammoniacal nitrogen in the soil due to the initial volatilization, the intense fertilizer immobilization/nitrification reactions (Martikainen, 1985; Recous et al., 1990) and the frequent rainfall between 15 and 30 days after nitrogen fertilization, which incorporated the remaining urea- $\mathrm{N}$ from the surface into the soil.

The cumulative $\mathrm{NH}_{3}-\mathrm{N}$ losses measured by the $\mathrm{SOC}$ represented $63,66,69$ and $62 \%$ of the total emissions in the first six days of the study for the urea- $\mathrm{N}$ rates of 50,100, 150 and $200 \mathrm{~kg} \mathrm{ha}^{-1}$, respectively (Table 2). In this same period, Lara Cabezas \& Trivelin (1990) observed a mean accumulation of $95 \%$ of total volatilized $\mathrm{NH}_{3}-\mathrm{N}$ using a SOC for 37 days of evaluation in a controlled environment, confirming that the $\mathrm{NH}_{3}-\mathrm{N}$ losses occur primarily on the first days after fertilizer application. In the case of the $\mathrm{OC}$, the cumulative $\mathrm{NH}_{3}-\mathrm{N}$ volatilization for $\mathrm{N}$ rates of 50,100, 150 and $200 \mathrm{~kg} \mathrm{ha}^{-1}$ represented $70,31,50$ and $56 \%$ of the total $\mathrm{NH}_{3}-\mathrm{N}$ lost to the atmosphere, respectively. As previously discussed, the maintenance of the $\mathrm{OC}$ apparatus in fixed positions on the soil surface probably reduced the recovery of volatilized $\mathrm{NH}_{3}-\mathrm{N}$, compared with the SOC method, underestimating the cumulative $\mathrm{NH}_{3}$-N losses for $\mathrm{N}$ rates of 100,150 and $200 \mathrm{~kg} \mathrm{ha}^{-1}$.

Table 2. Cumulative $\mathrm{NH}_{3}-\mathrm{N}$ volatilization from urea applied onto sugarcane straw as estimated by two collection systems in different subperiods during the experiment

\begin{tabular}{lcccc}
\hline \multirow{2}{*}{$\begin{array}{c}\text { Collection } \\
\text { system }\end{array}$} & \multicolumn{4}{c}{ Daily rate of Cumulative $\mathbf{N H}_{3}$-N loss } \\
& $\left.\mathbf{5} \mathbf{k g ~ h a}^{-1}\right)$
\end{tabular}

(1) OC: semi-open static collector. ${ }^{2}$ OC: open collector with an absorber wrapped in PTFE film. * Means followed by different letters in each column, for each subperiod, differ significantly by Tukey's test $(p<0.05)$.
In the subperiod from 7 to 14 days, based on the entire $\mathrm{N}$ rates, the cumulative volatilization for SOC and $\mathrm{OC}$ represented, respectively, 24 and $30 \%$ of the total $\mathrm{NH}_{3}-\mathrm{N}$ released from soil. In the second half of the experiment, the $\mathrm{NH}_{3}-\mathrm{N}$ losses were lowest $(11 \%$ for SOC and $17 \%$ for OC). Lower accumulation of volatilized $\mathrm{NH}_{3}-\mathrm{N}$ usually occurs 10 days after urea application, depending on the environment and soil conditions (Sommer et al., 2004). Sommer \& Ersbøll (1996) used a sigmoid model to relate the cumulative $\mathrm{NH}_{3}-\mathrm{N}$ volatilization from urea to the time after application, showing that in clay soil, half of the total losses can occur between 2 and 7 days after $\mathrm{N}$ fertilizer application.

Despite the underestimation of volatilization for the initial stages (0-6 days), the amount of volatilized $\mathrm{NH}_{3}-\mathrm{N}$ in the $\mathrm{OC}$ system did differ from that in the SOC (Figure 4a); SOCs are considered to provide reliable estimates of the process due to the calibration of the system with ${ }^{15} \mathrm{~N}$. In a greenhouse experiment, Alves et al. (2011) observed no differences between a SOC and an OC in the quantification of $\mathrm{NH}_{3}-\mathrm{N}$ volatilized from soil. The estimates of mean $\mathrm{NH}_{3}-\mathrm{N}$ volatilization in relation to urea-N considering all rates (Figure $4 \mathrm{~b}$ ) were $22.0 \% \pm 4.7$ and $13.9 \% \pm 7.2$ for the SOC and OC, respectively. These $\mathrm{N}$ losses were within the estimated range (18-26\%) of total $\mathrm{NH}_{3}-\mathrm{N}$ emissions from the surface application of urea (Bouwman et al., 2002). The results are also similar to those of studies that evaluated $\mathrm{NH}_{3}-\mathrm{N}$ volatilization from urea applied onto sugarcane residues (Prammanee et al., 1989; Freney et al., 1994; Cantarella et al., 2008).

The best correlation between the amount of volatilized $\mathrm{NH}_{3}-\mathrm{N}$ absorbed by an $\mathrm{OC}(\mathrm{NVaOC})$ and the amount determined by a SOC (NVdSOC) was obtained with an exponential model (Figure 5). The efficiency of the OC varied non-linearly with the amount of NVdSOC. Lara Cabezas \& Trivelin (1990), evaluating the efficiency of SOCs, also found that the amounts of volatilized $\mathrm{NH}_{3}-\mathrm{N}$ fit an exponential model. Araújo et al. (2009), calibrating a semi-open static collector for the quantification of volatilized $\mathrm{N}$, observed that the recovery of $\mathrm{NH}_{3}-15 \mathrm{~N}$ in the collector rose linearly with the increase in the $\mathrm{NH}_{3}$ volatilization rate from soil.

The mean efficiency of the OC was $58.4 \%$ of the total $\mathrm{NH}_{3}-\mathrm{N}$ volatilized from soil for the NVdSOC range obtained at rates between 100 and $200 \mathrm{~kg} \mathrm{ha}^{-1}$ urea-N (Table 3). Lara Cabezas \& Trivelin (1990) reported an efficiency of $16.2 \%$ for a SOC, explained by the layout of the foam absorbers in the collector, which hinder air circulation within the chamber and thus decrease water evaporation from the soil in relation to the surrounding area. Araújo et al. (2009), studying a collector in which the interior air flow was free, observed an efficiency of $57 \%$. 


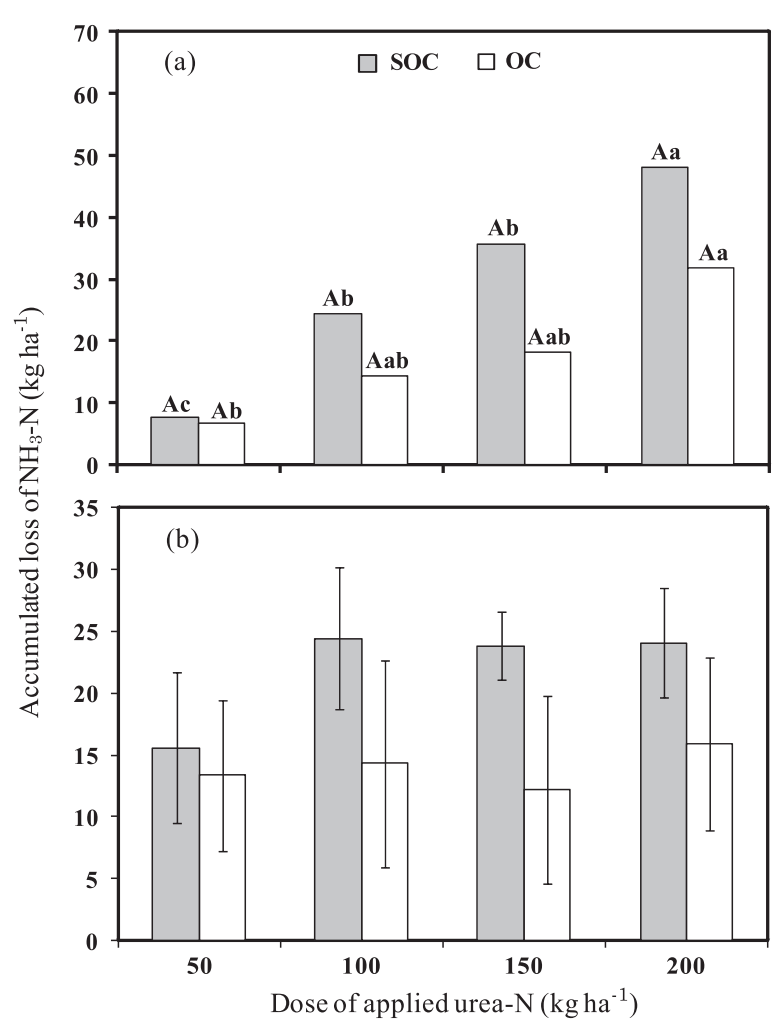

Figure 4. (a) Final $\mathrm{NH}_{3}-\mathrm{N}$ loss by surface application of urea on sugarcane straw estimated by a semi-open static collector (SOC) and an open collector with an absorber wrapped in PTFE film (OC). The different upper and lower case letters above the bars indicate significant differences according to Tukey's test $(p<0.05)$ between collector systems and $\mathrm{N}$ fertilizer rates, respectively. (b) Percentage of $\mathrm{NH}_{3}-\mathrm{N}$ loss. The vertical bars indicate standard deviations from the mean for $n=4$.

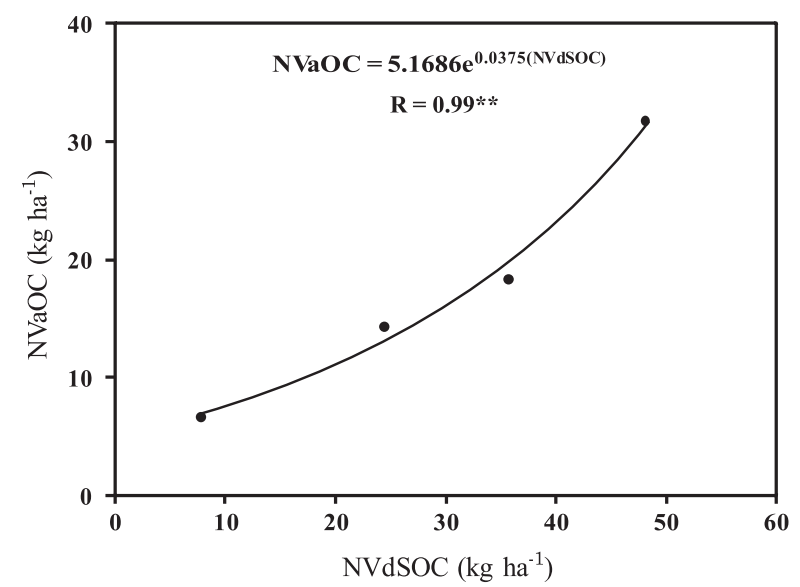

Figure 5. Regression curve between volatilized $\mathrm{NH}_{3}-\mathrm{N}$ absorbed by an open collector with an absorber wrapped in PTFE film (NVaOC) and volatilized $\mathrm{NH}_{3}-\mathrm{N}$ as determined by a semi-open static collector (NVdSOC). ${ }^{* *}$ : Significant at $1 \%$.
Table 3. An open collector with an absorber wrapped in PTFE film efficiency related to urea dose and volatilized $\mathrm{NH}_{3}-\mathrm{N}$ as determined by a semi-open static collector (NVdSOC) according to the selected best fit model

\begin{tabular}{|c|c|c|}
\hline $\mathrm{N}$ rate & NVdSOC & Efficiency \\
\hline \multicolumn{2}{|c|}{$\operatorname{kg~ha}^{-1} \mathrm{~N}$} & $\%$ \\
\hline 50 & 7.79 & $96.5 \mathrm{a}^{*}$ \\
\hline 100 & 24.43 & $53.2 \mathrm{~b}$ \\
\hline 150 & 35.73 & $55.5 \mathrm{~b}$ \\
\hline 200 & 48.09 & $66.6 \mathrm{~b}$ \\
\hline
\end{tabular}

* Means followed by different letters differ significantly by Tukey's test $(p<0.05)$.

Therefore, it is evident that collection systems that favor airflow in the area of $\mathrm{NH}_{3}-\mathrm{N}$ capture are more efficient to quantify volatilization.

Since the efficiency of the OC method was related to the use of fixed chamber positions in the field, the rainfall did not reach the $\mathrm{N}$ fertilizer applied under the collector apparatus, preventing urea hydrolysis and decreasing volatilized $\mathrm{NH}_{3}-\mathrm{N}$, as confirmed in the first 6-d period. On the other hand, overestimations of $\mathrm{NH}_{3}$ - $\mathrm{N}$ volatilization could also occur when heavy rainfall does not reach the $\mathrm{N}$ fertilizer applied under the $\mathrm{OC}$, increasing the $\mathrm{NH}_{3}$ - $\mathrm{N}$ losses in comparison with places in the surroundings of the collector, where rainfall can incorporate the $\mathrm{N}$ fertilizer into the soil. Thus, for reliable estimations of $\mathrm{NH}_{3}-\mathrm{N}$ losses using the $\mathrm{OC}$ method it is highly recommendable that the collector position should be shifted after rainfall events and foam replacements periods, similarly as adopted for the SOC method.

\section{CONCLUSIONS}

1. Applying urea-N fertilizer over sugarcane straw results in losses of $\mathrm{NH}_{3}-\mathrm{N}$ of up to $24 \%$ of the applied rate.

2. Results of $\mathrm{NH}_{3}-\mathrm{N}$ volatilization measured by an absorber wrapped in PTFE film were not significantly different from those of a semi-open static collector.

3. The efficiency of the collection system varied non-linearly depending on the rate of $\mathrm{NH}_{3}-\mathrm{N}$ volatilized, with a mean value of $58.4 \%$ for the range of 100 to $200 \mathrm{~kg} \mathrm{ha}^{-1}$ of urea-N.

4. To ensure the reliability of estimations of $\mathrm{NH}_{3}-\mathrm{N}$ losses by the open collector method it is 
suggested to change the collector position after events of rainfall and absorber replacement.

\section{ACKNOWLEDGEMENTS}

We would like to thank the Research Support Foundation of the State of São Paulo (FAPESP) for the scholarship awarded to the first author (Process 2009/04691-2) and the National Council of Scientific and Technological Development (CNPq) for the financial support of the research project, of which the work presented in this article is a part (Process 574982/2008-6).

\section{LITERATURE CITED}

ALVES, A.C.; OLIVEIRA, P.P.A.; HERLING, V.R.; TRIVELIN, P.C.O.; LUZ, P.H.C.; ALVES, T.C.; ROCHETTI, R.C. \& BARIONI JÚNIOR, W. New methods to quantify $\mathrm{NH}_{3}$ volatilization from fertilized surface soil with urea. R. Bras. Ci. Solo, 35:133-140, 2011.

ARAÚJO, E.S.; MARSOLA, T.; MIYAZAWA, M.; SOARES, L.H.B.; URQUIAGA, S.; BODDEY, R.M. \& ALVES, B.J.R. Calibração de câmara semiaberta estática para quantificação de amônia volatilizada do solo. Pesq. Agropec. Bras., 44:769-776, 2009.

BARRIE, A. \& PROSSER, S.J. Automated analysis of lightelement stable isotopes by isotope ratio mass spectrometry. In: BOUTTON, T.W. \& YAMASAKI, S., ed. Mass spectrometry of soils. New York, Marcel Dekker, 1996. p.1-46.

BOUWMAN, A.F. \& BOUMANS, L.J.M. \& BATJES, N.H. Estimation of global $\mathrm{NH}_{3}$ volatilization loss from synthetic fertilizers and animal manure applied to arable lands and grasslands. Global Biogeochem. Cycl., 16:1024, 2002.

CABRERA, M.L.; KISSEL, D.E. \& BOCK, B.R. Urea hydrolysis in soils: Effects of urea concentration and soil pH. Soil Biol. Biochem., 23:1121-1124, 1991.

CABRERA, M.L.; KISSEL, D.E.; VAIO, N.; CRAIG, J.R.; REMA, J.A. \& MORRIS, L.A. Loblolly pine needles retain urea fertilizer that can be lost as ammonia. Soil Sci. Soc. Am. J., 69:1525-1531, 2005.

CABRERA, M.L.; KISSEL, D.E.; CRAIG, J.R.; QAFOKU, N.P.; VAIO, N.; REMA, J.A. \& MORRIS, L.A. Relative humidity controls ammonia loss from urea applied to loblolly pine. Soil Sci. Soc. Am. J., 74:543-549, 2010.

CALCINO, D.V. \& BURGESS, D.J.W. Effect of urea placement on crop cycle yields of green trash blanketed sugarcane ratoons. Proc. Austr. Soc. Sugar Cane Technol., 17:193-198, 1995.
CAMPANA, M. Coletores de amônia, fontes e formas de aplicação de nitrogênio em Panicum maximum cv. Tanzânia submetido a manejo intensivo. Botucatu, Universidade Estadual Paulista "Júlio de Mesquita Filho", 2008.77p. (MSc. Thesis)

CANTARELlA, H.; MATTOS JUNIOR, D.; QUAGGIO, J.A. \& RIGOLIN, A.T. Fruit yield of Valencia sweet orange fertilized with different $\mathrm{N}$ sources and the loss of applied N. Nutr. Cycl. Agroecosyst., 67:215-223, 2003.

CANTARELLA, H.; TRIVELIN, P.C.O.; CONTIM, T.L.M.; DIAS, F.L.F.; ROSSETTO, R.; MARCELINO, R.; COIMBRA, R.B. \& QUAGGIO, J.A. Ammonia volatilisation from urease inhibitor-treated urea applied to sugarcane trash blankets. Sci. Agric., 65:397-401, 2008.

COSTA, M.C.G.; VITTI, G.C. \& CANTARELLA, H. Volatilização de $\mathrm{N}-\mathrm{NH}_{3}$ de fontes nitrogenadas em cana-de-açúcar colhida sem despalha a fogo. R. Bras. Ci. Solo, 27:631-637, 2003.

FRENEY, J.R.; DENMEAD, O.T.; WOOD, A.W. \& SAFFIGNA, P.G. Ammonia loss following urea addition to sugar cane trash blankets. Proc. Austr. Soc. Sugar Cane Technol., 16:114-121, 1994.

FRENEY, J.R.; DENMEAD, O.T.; WOOD, A.W.; SAFFIGNA, P.G.; CHAPMAN, L.S.; HAM, G.J.; HURNEY, A.P. \& STEWART, R.L. Factors controlling ammonia loss from trash covered sugarcane field fertilized with urea. Fert. Res., 31:341-349, 1992.

GEE, G.W. \& BAUDER, J.W. Particle-size analysis. In: KLUTE, A., ed. Methods of soil analysis. Physical and mineralogical methods. 2.ed. Madison, ASA/SSSA, 1986. Part. 1. p.383411. (Agronomy Series, 9).

HAYSOM, M.B.; CHAPMAN, L.S. \& VALLIS, I. Recovery of nitrogen from ${ }^{15} \mathrm{~N}$ urea applied to a green cane trash blanket at Mackay. Proc. Austr. Soc. Sugar Cane Technol., 16:79-84, 1990.

KISSEL, D.E.; BREWER, H.L. \& ARKIN, G.F. Design and test of a field sampler for ammonia volatilization. Soil Sci. Soc. Am. J., 41:1133-1138, 1977.

KLOSE, S. \& TABATABAI, M.A. Urease activity of microbial biomass in soils as affected by cropping systems. Biol. Fert. Soils, 31:191-199, 2000.

LAEGREID, M.; BOCKMAN, O.C. \& KAARSTAD, O. Agriculture, fertilizers and the environment. Cambridge, CABI, 1999. $294 \mathrm{p}$.

LARA CABEZAS, W.A.R. \& TRIVELIN, P.C.O. Eficiência de um coletor semi-aberto estático na quantificação da ureia aplicada ao solo. R. Bras. Ci. Solo, 14:345-352, 1990.

LARA CABEZAS, W.A.R.; TRIVELIN, P.C.O.; BENDASSOLLI, J.A.; SANTANA, D.G. \& GASCHO, G.J. Calibration of a semi-open static collector for determination of ammonia volatilization from nitrogen fertilizers. Commn. Soil Sci. Plant Anal., 30:389-406, 1999.

MARTIKAINEN, P.J. Nitrification in forest soil of different $\mathrm{pH}$ as affected by urea, ammonium sulphate and potassium sulphate. Soil Biol. Biochem., 17:363-367, 1985. 
NÖMMIK, H. The effect of pellet size on the ammonia loss from urea applied to forest soils. Plant Soil, 39:309-318, 1973.

PRAMMANEE, P.; SAFFIGNA, P.G.; WOOD, A.W. \& FRENEY, J.R. Loss of nitrogen from urea and ammonium sulphate applied to sugar cane crop residues. Proc. Austr. Soc. Sugar Cane Technol., 11:76-84, 1989.

PRASERTSAK, P.; FRENEY, J.R.; DENMEAD, O.T.; SAFFIGNA, P.G.; PROVE, B.G. \& REGHENZANI, J.R. Effects of fertilizer placement on nitrogen loss from sugarcane in tropical Queensland. N. Nutr. Cycl. Agroecosyst., 62:229$239,2002$.

RAIJ, B.van; ANDRADE, J.C.; CANTARELLA, H. \& QUAGGIO, J.A., ed. Análise química para avaliação da fertilidade de solos tropicais. Campinas, Instituto Agronômico de Campinas, 2001. 285p.

RECOUS, S.; MARY, B. \& FAURIE, G. Microbial immobilization of ammonium and nitrate in cultivated soils. Soil Biol. Biochem., 22:913-922, 1990.

REIS, B.F.; VIEIRA, J.A.; KRUG, F.J. \& GINÉ, M.F. Development of a flow injections system two analytical paths for ammonium determination in soil extracts by conductometry. J. Braz. Chem. Soc., 8:523-528, 1997.

ROCHETTE, P.; ANGERS, D.A.; CHANTIGNY, M.H.; MACDONALD, J.D.; BISSONNETTE, N. \& BERTRAND, $\mathrm{N}$. Ammonia volatilization following surface application of urea to tilled and no-till soils: A laboratory comparison. Soil Tillage Res., 103:310-315, 2009.
SHERLOCK, R.R.; BLACK, A.S. \& SMITH, N.P. Microenvironment soil $\mathrm{pH}$ around broadcast urea granules and its relationship to ammonia volatilization. In: BACON, P.E.; EVANS, J.; STORRIER, R.R. \& TAYLOR, A.C., ed. Nitrogen cycling in temperate agricultural systems. Riverina Branch, Australian Society of Soil Science, 1987. p.316-326.

SOIL SURVEY STAFF. Keys to soil taxonomy. 11.ed. Washington, USDA, Natural Resources Conservation Service, 2010. $344 \mathrm{p}$.

SOMMER, S.G. \& ERSBØLL, S.K. Effect of air flow rate, lime amendments and chemical soil properties on the volatilization of ammonia from fertilizers applied to sandy soils. Biol. Fert. Soils, 21:53-60, 1996.

SOMMER, S.G. \& OLESEN, J.E. Effects of dry matter content and temperature on ammonia loss from surface-applied cattle slurry. J. Environ. Qual., 20:679-683, 1991.

SOMMER, S.G.; OLESEN, J.E. \& CHRISTENSEN, B.T. Effects of temperature, wind speed, and air humidity on ammonia volatilization from surface-applied cattle slurry. J. Agric. Sci., 117:91-100, 1991.

SOMMER, S.G.; SCHJOERRING, J.K. \& DENMEAD, O.T. Ammonia emission from mineral fertilizers and fertilized crops. Adv. Agron., 82:557-622, 2004.

SØRENSEN, P. \& JENSEN, E.S. Sequential diffusion of ammonium and nitrate from soil extracts to a polytetrafluoroethylene trap for ${ }^{15} \mathrm{~N}$ determination. Anal. Chim. Acta, 252:201-203, 1991. 
